\title{
A new fossil species of Attagenus Latreille (Coleoptera: Dermestidae) in Rovno and Baltic ambers, with a brief review of known fossil beetles from the Rovno amber Lagerstätte
}

\author{
Andris Bukejs ${ }^{1}$, Jiří Háva ${ }^{1,2}$, and Vitalii I. Alekseev ${ }^{3,4}$ \\ ${ }^{1}$ Institute of Life Sciences and Technologies, Daugavpils University, Vienības 13, Daugavpils, 5401, Latvia \\ ${ }^{2}$ Private Entomological Laboratory and Collection, Rýznerova 37, 25262 Únětice u Prahy, \\ Prague-West District, Czech Republic \\ ${ }^{3}$ Shirshov Institute of Oceanology, Russian Academy of Sciences, Nahimovskiy prospekt 36, Moscow, 117997, Russia \\ ${ }^{4}$ Kaliningrad Regional Amber Museum, Marshal Vasilevskii Square 1, Kaliningrad, 236016, Russia
}

Correspondence: Andris Bukejs (carabidae@inbox.lv)

Received: 1 March 2020 - Revised: 11 April 2020 - Accepted: 22 April 2020 - Published: 14 May 2020

\begin{abstract}
Based on two specimens originating from Eocene Rovno and Baltic ambers, Attagenus (Aethriostoma) gedanicissimus sp. nov. is described, illustrated and compared with the related fossil Mesozoic species A. (Aethriostoma) turonianensis Peris et Háva, 2016. The common beetle species for Baltic and Rovno ambers suggests the exceptional temporal and geographical closeness of palaeoecosystems that produced both amber deposits. An updated checklist of Coleoptera known from Rovno amber (57 species belonging to 20 families) is compiled and provided with a bibliography of the original descriptions. The registered Rovno amber beetle assemblage contains only eight species that also occur in Baltic amber (14\%), while the similarity at the generic level is $56 \%$ at the moment. The relationship between the Rovno and Baltic amber deposits and subjectiveness of present-day results of the beetle assemblage research are briefly discussed (urn:lsid:zoobank.org:pub:289B5A43C57A-4B75-8A15-6E61F4AFCD81).
\end{abstract}

\section{Introduction}

The problem of mutual affinity in the triad of the main European Palaeogene fossil resins (Baltic amber, Bitterfeld amber and Rovno amber) is still under discussion in the 20th century (Hoffeins and Hoffeins, 2003; Perkovsky et al., 2007; Weitschat, 2008; Szwedo and Sontag, 2009; Sontag and Szadziewski, 2011; Wolfe et al., 2016; Dunlop et al., 2018;
Mänd et al., 2018; Kypke and Solodovnikov, 2018). All these fossil resins are succinites, and all originate from geographically proximate localities of central and eastern Europe (from the southern Baltic area, eastern Germany, and southern Belarus and northern Ukraine) (Perkovsky et al., 2010a; Weitschat and Wichard, 2010; Rappsilber, 2016; Bogri et al., 2018). All these fossil resins are rich in bioinclusions (Spahr, 1981; Poinar, 1992; Perkovsky et al., 2003, 2010b, 2012; Weitschat and Wichard, 2002; Perkovsky, 2016a; Alekseev, 2017; Rappsilber and Wendel, 2019; etc.). Unfortunately, the biodiversity of these ambers is unevenly studied: the known beetle assemblage of Baltic amber is more than 8 times larger than the known beetle assemblage of Rovno amber and more as than 30 times larger than the known beetle assemblage of Bitterfeld amber (Alekseev, 2013, 2017; Bukejs et al., 2016). Differences in volume of knowledge make data statistically incorrect and unreliable and also cannot provide any arguments concerning the discussion about the age of these ambers.

The Dermestidae (Coleoptera) contains about 1680 valid taxa worldwide (Háva, 2015) and fossil representatives of this family are relatively frequent in ambers. Taxonomic and morphological diversity of Cretaceous Dermestidae suggests an ancient origin of this group with some lineages showing remarkable evolutionary stasis for almost 100 million years (Deng et al., 2017). In total, nine extinct species of the genus Attagenus Latreille, 1802 from fossil resin are documented to date. Five species belonging to the nominative subgenus have 
been described previously from the Eocene Baltic amber: $A$. hoffeinsorum Háva, Prokop et Hermann, 2006; A. balticus Háva, Prokop et Hermann, 2008; A. obesus Háva, Prokop et Hermann, 2008; A. yantarnyi Háva et Bukejs, 2012; and $A$. gorskii Háva, 2014. Three species of nominative subgenus have been described from the Cenomanian Burmese amber: A. burmiticus Cai, Hava et Huang, 2017; A. lundi Háva et Damgaard, 2017; and A. secundus Deng, Ślipiński, Ren et Pang, 2017. One species of the subgenus Aethriostoma Motschulsky, 1858 is known from the Turonian New Jersey amber: A. turonianensis Peris et Háva, 2016.

In the current paper, the second extinct species of the subgenus Aethriostoma is described and illustrated from early Cenozoic amber (Rovno and Baltic). Data about the Coleoptera described from Rovno amber are summarized and briefly discussed.

\section{Material and methods}

The material examined is deposited in the following collections:

- the Museum of Amber Inclusions, University of Gdańsk (Poland, MAIG);

- the private collection of Anders Damgaard (Holstebro, Denmark, ADC), subsequently deposited in the Zoological Museum, University of Copenhagen, Denmark.

The amber pieces were polished by hand, allowing improved views of the included specimens, and they were not subjected to any supplemental fixation.

Observations of the specimens were made using a Nikon $\mathrm{SMZ}^{\circledR} 745 \mathrm{~T}$ stereomicroscope. The photographs were taken using a Canon $70 D^{\circledR}$ camera with a macro lens (Canon MP-E $65 \mathrm{~mm}$ ). Extended depth of field at high magnifications was achieved by combining multiple images from a range of focal planes using Helicon Focus ${ }^{\circledR}$ v. 6.0.18 software. Measurements were taken using an ocular micrometer (expressed in millimetres).

\section{Systematic palaeontology}

Family Dermestidae Latreille, 1807

Subfamily Attageninae Casey, 1900

Tribe Attagenini Casey, 1900

Genus Attagenus Latreille, 1802

Subgenus Aethriostoma Motschulsky, 1858

\section{Remarks}

The studied amber beetles show the combination of characters unequivocally corresponding to Attagenini within Attageninae: prosternum not forming "collar", mouthparts free, antennal club with three compact antennomeres, abdomen with five visible ventrites and elytra not shortened.

The specimens considered here were assigned to the subgenus Aethriostoma within Attagenus based on the combination of the following characters: (1) disc of metaventrite nearly twice as wide as long and (2) body strongly convex and widely oval (in Attagenus s. str. disc of metaventrite nearly twice as long as wide, and body less convex and more narrowly obovate).

\section{Attagenus (Aethriostoma) gedanicissimus sp. nov. urn:1sid:zoobank.org:act:4CE59EC6-79B0-43D9- B7DD-602EF4C3AA21}

Figs. 1-2

\section{Type material}

Holotype: 6278 (ex. coll. Jonas Damzen JDC 8531) (MAIG); Rovno amber; adult, sex unknown. Complete beetle is included in subtriangular, transparent amber piece, with dimensions of $25 \mathrm{~mm} \times 19 \mathrm{~mm} \times 16 \mathrm{~mm}$ and maximum thickness of $6 \mathrm{~mm}$. Syninclusions consist of one specimen of Nematocera (Diptera) and numerous small to minute organic particles.

Paratype: "AlDlo 558" (ADC); Baltic amber; adult, sex unknown. Complete beetle is included in transparent amber piece, with dimensions of $23 \mathrm{~mm} \times 21 \mathrm{~mm}$ and maximum thickness of $5 \mathrm{~mm}$. Syninclusion consists of one specimen of Nematocera (Diptera).

\section{Type strata}

Rovno amber, upper Eocene (holotype); Baltic amber, middle Eocene (paratype).

\section{Etymology}

The epithet of the new species is the Latin adjective gedanicus in the superlative and is formed from Gedanum, the Latin name of Gdańsk where the specimen is deposited.

\section{Differential diagnosis}

Attagenus (Aethriostoma) gedanicissimus sp. nov. differs from the single known fossil representative of the subgenus, Attagenus (Aethriostoma) turonianensis Peris et Háva, 2016 (USA; Late Cretaceous: Turonian; New Jersey amber) in the following characters: antennomere 11 shorter than antennomeres 9-10 combined; pronotum strongly transverse, $3 \times$ as wide as long; abdominal sutures almost straight; and larger body size; while in A. turonianensis antennomere 11 as long as antennomeres 9-10 combined; pronotum transverse, $2.1 \times$ as wide as long; abdominal sutures concave; and distinctly smaller body size $(1.81 \mathrm{~mm})$. 

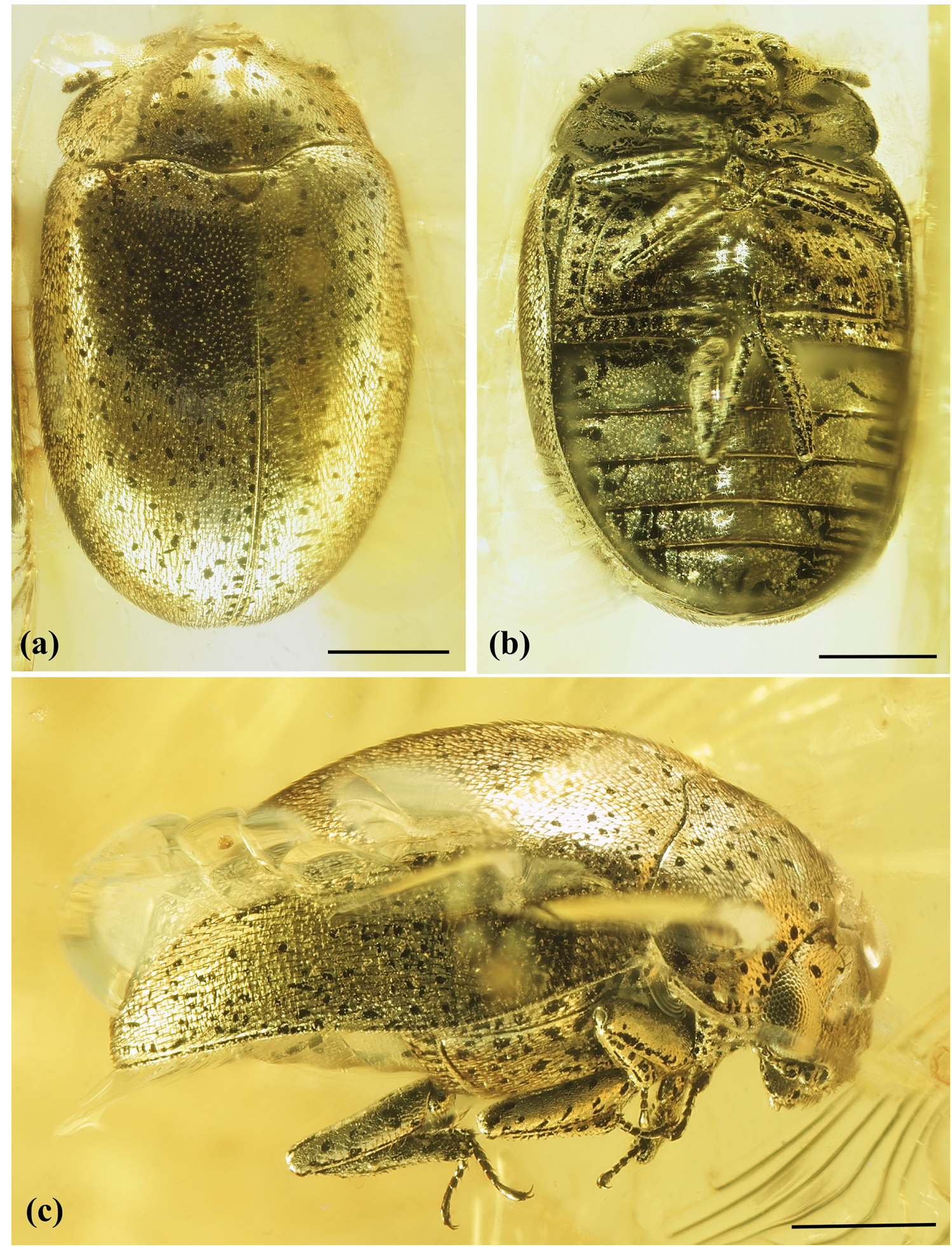

Figure 1. Attagenus (Aethriostoma) gedanicissimus sp. nov., holotype, 6278 (MAIG): (a) habitus, dorsal view; (b) habitus, ventral view; (c) habitus, right lateral view. Scale bars $=0.5 \mathrm{~mm}$. 

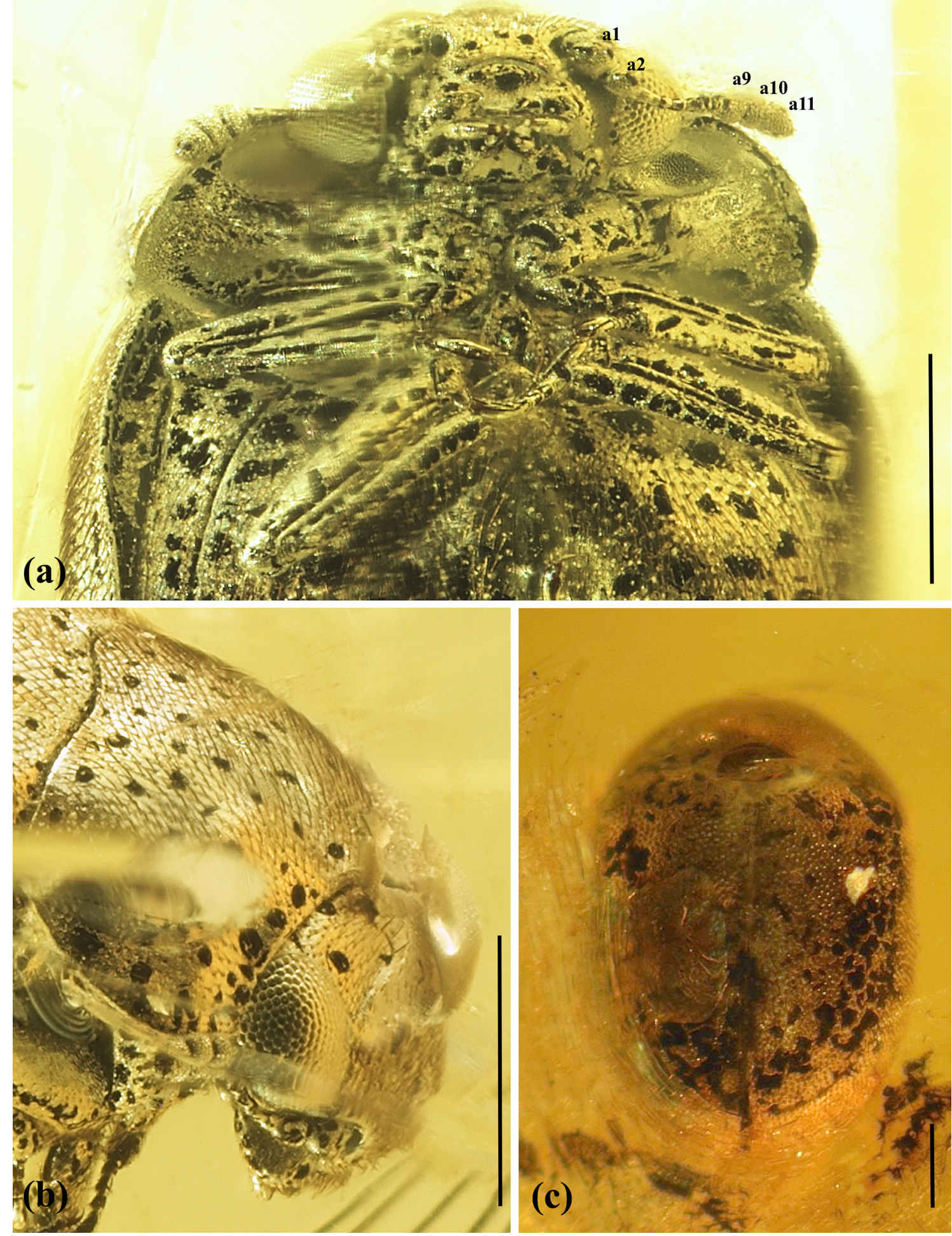

Figure 2. Attagenus (Aethriostoma) gedanicissimus sp. nov.: (a) details of forebody, ventral view, holotype, 6278 (MAIG); (b) head and pronotum, lateral view, holotype, 6278 (MAIG); (c) habitus, dorsal view, paratype AlDlo 558 (ADC). Scale bars $=0.5 \mathrm{~mm}$. Abbreviations: a1-a11 are antennomeres $1-11$ respectively. 
The new Eocene species A. (Aethriostoma) gedanicissimus sp. nov. differs from extant representatives of the subgenus in the unicolour blackish body and appendages (in contrast to the rufous palpi and basis of antennae in A. philippinensis Háva, 2016 and the entirely rufous appendages in $A$. sparsutus (Reitter, 1881)) and uniform, dark and comparatively sparse setation of dorsum (in contrast to the golden setation of A. philippinensis Háva, 2016 distinctly denser on pronotal base). Dorsal setation does not form any lightcoloured patterns: fasciae or maculae (in contrast to A. undulatus (Motschulsky, 1858) and A. irroratus (Blackburn, 1903)). Additionally, in new fossil species the antennomere 11 is slightly tapered beyond the midpoint.

\section{Description of holotype}

Measurements: total body length $2.8 \mathrm{~mm}$; pronotal length $0.5 \mathrm{~mm}$, pronotum maximum width $1.5 \mathrm{~mm}$; elytral length $2.5 \mathrm{~mm}$, elytral maximum width $1.7 \mathrm{~mm}$.

Body widely oval, $1.6 \times$ as long as wide, convex; integument unicoloured, dark brown (as preserved); pubescence homogenous and moderately dense, consists of fine, short, recumbent, dark setae (pronotal and elytral disc and venter with finer pubescence); punctation homogenous, dense and fine.

Head hypognathous, much narrower than anterior margin of pronotum. Frons flat; frontal median ocellus apparently present. Compound eyes large, oval, prominent, entire, with distinct facets. Mouthparts free. Antennae slightly shorter than head wide (including eyes), sparsely pubescent; 11 antennomeres, clavate, with three antennomeres forming compact club and comprising about one-third of antennal length; scape large, subspherical, $1.2 \times$ as long as wide; pedicle subcylindrical, $1.5 \times$ as long as wide, smaller than scape, and distinctly wider than antennomere 3; antennomeres 36 cylindrical, elongate, $1.7-2.5 \times$ as long as wide, narrow, about $0.6 \times$ as wide as pedicle; antennomeres $7-8$ nearly as wide as long, slightly dilated apically; antennomeres 9-10 strongly transverse, 1.8-2.0 $\times$ as wide as long, dilated apically; antennomere 11 ovoid, about $1.1 \times$ as long as wide, with slightly pointed apex.

Pronotum strongly transverse, about $3 \times$ as wide as long, base of pronotum nearly as wide as elytral base; lateral margins of pronotum widely rounded, posterior margin bisinuated, narrowly bordered. Hypomeron with deep antennal cavity. Prosternum not forming "collar", covered with strong microreticulation.

Scutellar shield large, triangular with rounded apex.

Elytra about $1.3 \times$ as long as wide, widest at middle of elytral length, slightly narrowed posteriad, with anterior margin deeply concave medially, humeral callus weak. Epipleura narrow, deeply impressed, widest at humeri, reaching anterior margin of abdominal ventrite 1. Metaventrite convex, with longitudinal median line, transverse, about $2 \times$ as wide as long; posterior margin slightly concave, anterior margin bisinuated, with subtriangular process medially. Metepisternum wide, $2.6 \times$ as long as wide anteriorly.

Legs slender, moderately long; covered with microreticulation and fine, short, recumbent setae. Femora flattened, with longitudinal groove ventrally. Tibiae almost straight (protibiae slightly curved), subcylindrical, with short spine apically, tibia and femora subequal in length; protibia slightly dilated apically, slightly shorter than meso- and metatibia. Tarsi thin, moderately long, about $0.5 \times$ as long as tibia; protarsus slightly shorter than meso- and metatarsus; relative length ratios of metatarsomeres $1-5$ equal to 1-1-1-1-3. Claws thin and long, free, simple.

Abdomen with five visible ventrites; abdominal sutures almost straight (sutures between ventrites 3 and 5 slightly concave); ventrite 5 with widely rounded apical margin. Relative length ratios of ventrites 1-5 (medially) equal to 10-7-6-610 .

\section{Paratype}

Measurements: total body length $2.8 \mathrm{~mm}$; pronotal length $0.6 \mathrm{~mm}$, pronotum maximum width $1.4 \mathrm{~mm}$; elytral length $2.2 \mathrm{~mm}$, elytral maximum width $1.9 \mathrm{~mm}$.

\section{Discussion}

\subsection{Rovno amber as a geographical variety of Baltic amber}

Amber that is chemically similar to Baltic amber is widespread in the Dnieper River basin in Belarus and Ukraine (Savkevich, 1970), in the Kiev (upper Eocene) and Kharkov (lower Oligocene) formations, and in the Quaternary deposits (Zherikhin and Eskov, 1999). The most important amber deposits were discovered near Klesov and near Dubrovitsa in the Rovno region (Ukraine), where the amber has been mined since the 1980s. Some authors believe that this Rovno amber was transported to the Dnieper area from the north across the sea and thus originates from the same region as Baltic amber (e.g. Katinas, 1987). Others suggest a local origin from the Ukrainian shield (e.g. Perkovsky et al., 2007; Mänd et al., 2018). A comparison of inclusions may offer a clue to this problem (Zherikhin and Eskov, 1999), but in the current state of knowledge, the distribution of the different groups of insects gives equivocal results. "The faunas of Ceratopogonidae enclosed in amber from Rovno, Bitterfeld and the Baltic are very similar, showing that they inhabited similar palaeoenvironments in the same palaeogeographic region" (Sontag and Szadziewski, 2011, p. 781), whereas the data obtained from comparison of the Hymenoptera assemblages "provide evidence supporting the previously proposed suggestion on the different origin of four main European sources of succinite" (Perkovsky, 2018, p. 353). On the basis of comprehensive research on one systematic group of Rovno beetles, the Scydmaeninae, it is con- 
cluded that subtropical and tropical taxa were present in the region where Rovno amber formed, whereas the Baltic amber beetle assemblage was more hygrophilous and adapted to a colder climate in general (Jałoszyński and Perkovsky, 2016).

Taking into account the existence of many small Eocene amber outcrops in Poland, Ukraine and Belarus (and possible slight variability in their bioinclusions), the naming "Baltic amber sensu lato" for all these local types of succinites including Belarus amber, Rovno amber, etc., could be used. However, we follow the traditional view and use the name "Rovno amber" as separate from "amber type".

\subsection{Checklist of Coleoptera known from Rovno amber}

As an additional part of the study, a checklist of all known Coleoptera from Rovno amber is compiled and presented below. Synonymy for two taxa is provided according to Gimmel et al. (2019) and Reike et al. (2017).

Family Micromalthidae

1. Micromalthus priabonicus Perkovsky, 2016b

Family Leiodidae

2. Prionochaeta gratschevi Perkovsky, 2009

Family Ptiliidae

3. Ptinella rovnoensis Polilov et Perkovsky, 2004

Family Staphylinidae

4. Baltostigus cf. horribilis Jałoszyński, 2016

5. Baltostigus substriatus Jałoszyński et Perkovsky, 2019

6. Cephennomicrus giganteus Jałoszyński et Perkovsky, 2016

7. Dysanabatium kechrimparense Bogri, Solodovnikov et Żyła, 2018

8. Euconnus palaeogenus Jałoszyński et Perkovsky, 2016

9. Glaesoconnus unicus Jałoszyński et Perkovsky, 2016

10. Leptusa (Protoleptusa) defuncta Semenov, Perkovsky et Petrenko, 2001

11. Orsunius electronefelus Kypke et Solodovnikov, 2018

12. Rovnoleptochromus ableptonoides Jałoszyński et Perkovsky, 2016

13. Rovnoscydmus frontalis Jałoszyński et Perkovsky, 2016

14. Rovnoscydmus microscopicus Jałoszyński et

Perkovsky, 2016

15. Stenichnus proavus Jałoszyński et Perkovsky, 2016

16. Vertheia quadrisetosa Jałoszyński et Perkovsky, 2016
Family Cantharidae

17. Malthodes perkovskyi Kazantsev, 2010

18. Malthodes rovnoensis Kazantsev et Perkovsky 2014

19. Mimoplatycis notha Kazantsev, 2013

20. Cacomorphocerus meridionalis Kazantsev et

Perkovsky, 2020

Family Dermestidae

21. Dermestes (s. str.) vetustus Zhantiev, 2006

22. Attagenus (Aethriostoma) gedanicissimus sp. nov.

Family Ptinidae

23. Sucinoptinus brevipennis Bellés et Perkovsky, 2016

24. Sucinoptinus rovnoensis Bellés et Perkovsky, 2016

Family Malachiidae

25. Protocephaloncus perkovskyi Tshernyshev, 2016

Family Smicripidae

26. Smicrips fudalai Kupryjanowicz, Lyubarsky et Perkovsky, 2019

Family Cyclaxyridae

27. Neolitochropus bedovoyi (Lyubarsky et Perkovsky, 2011a)

= Stilbus bedovoyi Lyubarsky et Perkovsky, 2011b

= Neolitochropus hoffeinsorum Lyubarsky et

Perkovsky 2016

Family Cryptophagidae

28. Cryptophagus alexagrestis Lyubarsky et Perkovsky, 2011a

29. Cryptophagus harenus Lyubarsky et Perkovsky, 2012b

30. Micrambe sarnensis Lyubarsky et Perkovsky, 2010

31. Telmatophilus sidorchukae Lyubarsky et Perkovsky, 2020

Family Erotylidae

32. Xenohimatium rovnense Lyubarsky et Perkovsky, $2012 \mathrm{a}$

Family Latridiidae

33. Latridius alexeevi Bukejs, Kirejtshuk et Rücker, 2011

= Latridius usovae Sergi et Perkovsky, 2014

Family Melandryidae

34. Orchesia rasnitzyni Nikitsky, 2011

Family Mordellidae

35. Glipostena ponomarenkoi Odnosum et Perkovsky, 2009 
Family Scraptiidae

36. Anaspis (Spanisa) horaki Perkovsky et Odnosum, 2009

Family Chrysomelidae

37. Archealtica convexa Nadein in Nadein, Perkovsky et

Moseyko, 2015

38. Crepidodera decolorata Nadein et Perkovsky, 2010

39. Manobriomorpha eocenica Nadein in Nadein et

Perkovsky, 2010

40. Paleophaedon minutus Nadein et Perkovsky, 2010

41. Psyllototus progenitor Nadein in Nadein et

Perkovsky, 2010

42. Taphioporus rovnoi Moseyko et Perkovsky in

Nadein, Perkovsky et Moseyko, 2015

Family Anthribidae

43. Glaesotropis diadiasashai Gratshev et Perkovsky, 2008

44. Eduardoxenus unicus Legalov, Nazarenko et

Perkovsky, 2018

Family Rhynchitidae

45. Pseudomesauletes groehni Bukejs et Legalov, 2019a

Family Curculionidae

46. Arostropsis perkovskyi Bukejs et Legalov, 2019b

47. Caulophilus martynovae Legalov, Nazarenko et

Perkovsky, 2019

48. Caulophilus zherikhini Nazarenko, Legalov et

Perkovsky, 2011

49. Dorytomus vlaskini Legalov, Nazarenko et

Perkovsky, 2019

50. Klesovia pubescens Petrov et Perkovsky, 2018

51. Paonaupactus gracilis Legalov, Nazarenko et

Perkovsky, 2019

52. Paonaupactus katyae Legalov, Nazarenko et

Perkovsky, 2019

53. Protoceletes hirtus Nazarenko et Perkovsky, 2016

54. Rovnoslonik damzeni Legalov, Nazarenko et

Perkovsky, 2019

55. Stenommatomorphus hexarthrus Nazarenko in

Nazarenko et Perkovsky, 2009

56. Taphramites rovnoensis Petrov et Perkovsky, 2008

57. Xylechinus mozolevskae Petrov et Perkovsky, 2008

The known assemblage of the Rovno amber Coleoptera composes 57 species belonging to 50 genera and 20 families. A total of 49 species are known only from this Lagerstätte, and eight species (Anaspis horaki, Attagenus gedanicissimus sp. nov., Baltostigus horribilis, Dysanabatium kechrimparense, Latridius alexeevi, Mimoplatycis notha, Neolitochropus bedovoyi, Orchesia rasnitzyni) are also known or are primarily described from Baltic amber (i.e. are common for these two ambers). From the listed beetle genera with described species, 28 genera $(56 \%)$ are common with Baltic amber, i.e. have described analogues; 13 genera are palaeoendemic for Rovno amber (26\%); and 9 genera (18\%) are recent but have no described species in Baltic amber.

The study of Rovno amber was focused first of all on new descriptions and on the search for new taxa, while studies on the similarities and differences with the assemblage of Baltic amber species were mainly beyond the scope of the current palaeontological papers. The ratio of 49 palaeoendemic species to eight species common with Baltic amber is a subjective present-day stage of research, but not an objective and real ratio of common and "endemic" Coleoptera in these ambers. The species list of the Rovno amber beetles does not contain any data on many species-rich beetle families in Baltic amber (Aderidae, Carabidae, Cerambycidae, Cleridae, Elateridae, and Scirtidae) at all: although these families are known in Rovno amber, the representatives are still without generic or specific attribution. We suppose that the lack of such information is a very important part of the general scarcity of reliable data for analysis at the moment.

Data availability. No data sets were used in this article.

Author contributions. AB and VIA conceived of the presented idea and wrote the manuscript with input from $\mathrm{JH}$. $\mathrm{AB}$ designed the study and prepared the description of the new species, JH supervised the differential diagnosis of the new species, VIA performed the list of Rovno fossil beetles. All authors provided critical feedback and helped to shape the research, analysis and manuscript.

Competing interests. The authors declare that they have no conflict of interest.

Acknowledgements. The authors are sincerely grateful to Elżbieta Sontag (Museum of Amber Inclusions, University of Gdańsk, Poland) and Anders Damgaard (Holstebro, Denmark) for the loan and to Jonas Damzen (Vilnius, Lithuania) for informing us about the interesting specimen, assistance during our amber research and permission to use photographs of the holotype. The authors are grateful to Andreas Herrmann (Stade, Germany) and the one anonymous reviewer for their helpful comments and corrections on an earlier version of this paper. The study of VIA was done with the support of the state assignment of IO RAS (theme no. 0149-2019-0013).

Financial support. This research has been supported by the IO RAS (grant no. 0149-2019-0013). 
Review statement. This paper was edited by Florian Witzmann and reviewed by Andreas Herrmann and one anonymous referee.

\section{References}

Alekseev, V. I.: The beetles (Insecta: Coleoptera) of Baltic amber: the checklist of described species and preliminary analysis of biodiversity, Zool. Ecol., 23, 5-12, https://doi.org/10.1080/21658005.2013.769717, 2013.

Alekseev, V. I.: Coleoptera from the middle-upper Eocene European ambers: generic composition, zoogeography and climatic implications, Zootaxa, 4290, 401-443, https://doi.org/10.11646/zootaxa.4290.3.1, 2017.

Bellés, X. and Perkovsky, E. E.: New data on the genus Sucinoptinus (Coleoptera, Ptinidae) from Rovno amber, Vestnik zoologii, 50, 17-22, https://doi.org/10.1515/vzoo-2016-0002, 2016.

Blackburn, T.: Further notes on Australian Coleoptera, with descriptions of new genera and species. XXXII, T. Roy. Soc. South Aust., 27, 91-182, 1903.

Bogri, A., Solodovnikov, A., and Żyła, D.: Baltic amber impact on historical biogeography and palaeoclimate research: oriental rove beetle Dysanabatium found in the Eocene of Europe (Coleoptera, Staphylinidae, Paederinae), Pap. Palaeontol., 4, 433-452, https://doi.org/10.1002/spp2.1113, 2018.

Bukejs, A. and Legalov, A. A.: The first record of Rhynchitidae (Coleoptera) from Rovno amber, Entomol. Fennica, 30, 168172, https://doi.org/10.33338/ef.87174, 2019a.

Bukejs, A. and Legalov, A. A.: First record of the tribe Naupactini (Coleoptera: Curculionidae) in Rovno amber, Foss. Rec., 22, 2530, https://doi.org/10.5194/fr-22-25-2019, 2019b.

Bukejs, A., Kirejtshuk, A. G., and Rücker, W. H.: New species of Latridius (Coleoptera: Latridiidae) from Baltic amber, Baltic Journal of Coleopterology, 11, 203-207, 2011.

Bukejs, A., Biondi, M., and Alekseev, V. I.: New records and species of Crepidodera Chevrolat (Coleoptera: Chrysomelidae) in Eocene European amber, with a brief review of described fossil beetles from Bitterfeld amber, Zootaxa, 4193, 390-400, https://doi.org/10.11646/zootaxa.4193.2.13, 2016.

Casey, T. L.: Review of the American Corylophidae, Cryptophagidae, Tritomidae and Dermestidae with other studies, Journal New York Entomological Society, New York, 8, 51-172, 1900.

Cai, Ch., Háva, J., and Huang, D.: The earliest Attagenus species (Coleoptera: Dermestidae: Attageninae) from Upper Cretaceous Burmese amber, Cretaceous Res., 72, 95-99, https://doi.org/10.1016/j.cretres.2016.12.018, 2017.

Deng, C., Ślipiński, A., Ren, D., and Pang, H.: New Cretaceous carpet beetles (Coleoptera: Dermestidae) from Burmese amber, Cretaceous Res., 76, 1-6, https://doi.org/10.1016/j.cretres.2017.04.004, 2017.

Dunlop, J. A., Kotthoff, U., Hammel, J. U., Ahrens, J., and Harms, D.: Arachnids in Bitterfeld amber: A unique fauna of fossils from the heart of Europe or simply old friends?, Evolutionary Systematics, 2, 31-44, https://doi.org/10.3897/evolsyst.2.22581, 2018.

Gimmel, M. L., Szawaryn, K., Cai, C., and Leschen, R. A. B.: Mesozoic sooty mould beetles as living relicts in New Zealand, P. Roy. Soc. B, 286, 20192176, https://doi.org/10.1098/rspb.2019.2176, 2019.
Gratshev, V. G. and Perkovsky, E. E.: New species of the genus Glaesotropis (Insecta: Coleoptera: Anthribidae) from Rovno amber, Paleontol. J., 42, 60-62, https://doi.org/10.1007/s11492008-1009-8, 2008.

Háva, J.: New data on fossil species from Baltic amber with description of a new species (Coleoptera: Dermestidae), Arquivos Entomológicos, 10, 211-216, 2014.

Háva, J.: World Catalogue of Insects, Vol. 13, Dermestidae (Coleoptera), Leiden/Boston, Brill, 2015.

Háva, J.: A contribution to knowledge of Dermestidae (Coleoptera: Bostrichiformia) from the Philippines, Acta Biologica Universitatis Daugavpiliensis, 16, 129-134, 2016.

Háva, J. and Bukejs, A.: Attagenus yantarnyi sp. nov., a new species from Baltic amber (Coleoptera: Dermestidae), Baltic Journal of Coleopterology, 12, 155-158, 2012.

Háva, J. and Damgaard, A. L.: Attagenus lundi sp. nov. from Cretaceous Burmese amber (Coleoptera: Dermestidae: Attageninae), Studies and Reports, Taxonomical Series, 13, 303-306, 2017.

Háva, J., Prokop, J., and Herrmann, A.: New fossil dermestid beetles (Coleoptera: Dermestidae) from Baltic amber, Acta Societatis Zoologicae Bohemicae, 69, 281-287, 2006.

Háva, J., Prokop, J., and Herrmann, A.: New fossil dermestid beetles (Coleoptera: Dermestidae) from the Baltic amber - III, Acta Societatis Zoologicae Bohemicae, 71, 151-157, 2008.

Hoffeins, Ch. and Hoffeins, H. W.: Untersuchungen über die Häufigkeit von Inklusen in Baltischem und Bitterfelder Bernstein (Tertiär, Eozän) aus unselektierten Aufsammlungen unter besonderer Berücksichtigung der Ordnung Diptera, Studia dipterologica, 10, 381-392, 2003.

Jałoszyński, P.: A new Eocene genus of ant-like stone beetles sheds new light on the evolution of Mastigini, J. Paleontol., 89, 10561067, https://doi.org/10.1017/jpa.2015.75, 2016.

Jałoszyński, P. and Perkovsky, E. E.: Diversity of Scydmaeninae (Coleoptera: Staphylinidae) in Upper Eocene Rovno amber, Zootaxa, 4157, 1-85, https://doi.org/10.11646/zootaxa.4157.1.1, 2016.

Jałoszyński, P. and Perkovsky, E. E.: The Mastigitae genus $\dagger$ Baltostigus in Upper Eocene Rovno amber (Coleoptera: Staphylinidae: Scydmaeninae), Zootaxa, 4661, 594-600, https://doi.org/10.11646/zootaxa.4661.3.12, 2019.

Katinas, V. I.: The amber-bearing terrigenous-glaucinitic formation of the Paleogene of Baltic area and Belorussia, in: Tektonika, fatsii i formatsii zapada Vostochno-Evropeyskoy platformy, Nauka i tekhnika, Minsk, 184-189, 1987 (in Russian).

Kazantsev, S. V.: New Malthodes (Insecta: Cantharidae: Coleoptera) from the Rovno amber (Upper Eocene of Ukraine), Russian Entomological Journal, 19, 105-107, 2010.

Kazantsev, S. V.: New taxa of Baltic amber soldier beetles (Insecta: Coleoptera: Cantharidae) with synonymic and taxonomic notes, Russian Entomological Journal, 22, 283-293, 2013.

Kazantsev, S. V. and Perkovsky, E. E.: A new Malthodes and some other interesting soldier beetles (Coleoptera: Cantharidae) from Late Eocene Rovno amber, Russian Entomological Journal, 23, 113-116, 2014.

Kazantsev, S. V. and Perkovsky, E. E.: The first Cacomorphocerus species (Coleoptera, Cantharidae) from Rovno amber: a second species of the genus with 11-segmented antennae, Zootaxa, 4751, 395-400, https://doi.org/10.11646/zootaxa.4751.2.14, 2020. 
Kupryjanowicz, J., Lyubarsky, G. Y., and Perkovsky, E. E.: A new species of the family Smicripidae (Coleoptera: Cucujoidea) from Rovno amber, Paleontological Journal, 53, 165171, https://doi.org/10.1134/S0031030119020059, 2019.

Kypke, J. L. and Solodovnikov, A.: Every cloud has a silver lining: $\mathrm{X}$-ray micro-CT reveals Orsunius rove beetle in Rovno amber from a specimen inaccessible to light microscopy, Hist. Biol., https://doi.org/10.1080/08912963.2018.1558222, 2018.

Latreille, P. A.: Histoire Naturelle, Générale et Particuliere des Crustacés et des Insectes. III, F. Dufart, Paris, 1802.

Latreille, P. A.: Genera Crustaceorum et Insectorum secundum ordinem naturalem in familias disposita, iconibus exemplisque plurimis explicata. II. Parisiis et Argentorati, A. Koenig, Paris, 1807.

Legalov, A. A., Nazarenko, V. Y., and Perkovsky, E. E.: A new genus of fungus weevils (Coleoptera: Anthribidae) in Rovno amber, Foss. Rec., 21, 207-212, https://doi.org/10.5194/fr-21-2072018, 2018.

Legalov, A. A., Nazarenko, V. Y., and Perkovsky, E. E.: New weevils (Coleoptera: Curculionidae) from Rovno amber, Paleontol. J., 53, 1045-1059, https://doi.org/10.1134/S0031030116090094, 2019.

Lyubarsky, G. Yu. and Perkovsky, E. E.: The first Eocene species of the genus Micrambe (Coleoptera, Clavicornia, Cryptophagidae), Vestnik zoologii, 44, 275-279, 2010.

Lyubarsky, G. Yu. and Perkovsky, E. E.: Third contribution on Rovno amber silken fungus beetles: a new Eocene species of Cryptophagus (Coleoptera, Clavicornia, Cryptophagidae), ZooKeys, 130, 255-261, https://doi.org/10.3897/zookeys.130.1321, 2011a.

Lyubarsky, G. Yu. and Perkovsky, E. E.: New species of Stilbus (Coleoptera, Clavicornia, Phalacridae) from the Late Eocene Rovno amber, Vestnik zoologii, 45, 187-190, 2011 b.

Lyubarsky, G. Yu. and Perkovsky, E. E.: A new genus of Erotylidae from Eocene amber (Coleoptera: Clavicornia), Russian Entomological Journal, 21, 35-38, 2012a.

Lyubarsky, G. Yu. and Perkovsky, E. E.: The first Eocene species of the genus Cryptophagus (Coleoptera, Clavicornia, Cryptophagidae), Vestnik zoologii, 46, 83-87, 2012 b.

Lyubarsky, G. Y. and Perkovsky, E. E.: A new genus, Neolitochropus (Coleoptera: Cucujoidea: Phalacridae), from the Upper Eocene Bitterfeld amber, Russian Entomological Journal, 25, 249-253, 2016.

Lyubarsky, G. Y. and Perkovsky, E. E.: First Rovno amber species of the genus Telmatophilus (Coleoptera: Clavicornia: Cryptophagidae) from Veselukha floodplain, Invertebrate Zoology, 17, 25-35, 2020.

Mänd, K., Muehlenbachs, K., McKellar, R. C., Wolfe, A. P., and Konhauser, K.: Distinct origins for Rovno and Baltic ambers: evidence from carbon and hydrogen stable isotopes, Palaeogeogr. Palaeocl., 55, 265-273, https://doi.org/10.1016/j.palaeo.2018.06.004, 2018.

Motschulsky, V. I.: II. Entomologie spéciale. Insectes des Indes orintales, Études Entomologiques, Helsingfors, 7, 20-122, 1858.

Nadein, K. S. and Perkovsky, E. E.: New taxa of Chrysomelidae (Insecta: Coleoptera) from Rovno amber, Late Eocene, Acta Geol. Sin., 84, 772-782, 2010.

Nadein, K. S., Perkovsky, E. E., and Moseyko, A. G.: New Late Eocene Chrysomelidae (Insecta: Coleoptera) from Baltic,
Rovno and Danish ambers, Pap. Palaeontol., 2, 117-137, https://doi.org/10.1002/spp2.1034, 2015.

Nazarenko, V. Y. and Perkovsky, E. E.: A new genus and species of Dryophthorid weevils (Coleoptera, Dryophthoridae: Stromboscerinae) from the Rovno amber, Paleontol. J., 43, 1097-1100, https://doi.org/10.1134/S003103010909010X, 2009.

Nazarenko, V. Y. and Perkovsky, E. E.: A new species of Derelomine weevils (Coleoptera, Curculionidae, Curculioninae: Acalyptini) from the Rovno amber, Paleontol. J., 50, 991-996, https://doi.org/10.1134/S0031030116090094, 2016.

Nazarenko, V. Y., Legalov, A. A., and Perkovsky, E. E.: A new species of the genus Caulophilus Woll. (Coleoptera: Curculionidae: Cossoninae) from the Rovno amber, Paleontol. J., 45, 287290, https://doi.org/10.1134/S0031030111030105, 2011.

Nikitsky, N. B.: New species of the genus Orchesia Latr. from the Upper Eocene (Coleoptera: Tenebrionoidea), Paleontol. J., 5, 8284, https://doi.org/10.1134/S003103011105008X, 2011.

Odnosum, V. K. and Perkovsky, E. E.: New species of the tumbling flower beetle genus Glipostena (Insecta: Coleoptera: Mordellidae) from Rovno amber, Paleontol. J., 43, 1095-1096, https://doi.org/10.1134/S0031030109090093, 2009.

Peris, D. and Háva, J.: New species from Late Cretaceous New Jersey amber and stasis in subfamily Attageninae (Insecta: Coleoptera: Dermestidae), J. Paleontol., 90, 491-498, https://doi.org/10.1017/jpa.2016.51, 2016.

Perkovsky, E. E.: Novy vid roda Prionochaeta (Coleoptera, Leiodidae, Cholevinae) iz rovenskogo yantarya [New species of Prionochaeta (Coleoptera, Leiodidae, Cholevinae) from Rovno amber], Vestnik zoologii, 43, 373-377, 2009.

Perkovsky, E. E.: Tropical and Holarctic ants in Late Eocene ambers, Vestnik zoologii, 50, 111-122, 2016a.

Perkovsky, E. E.: A new species of Micromalthidae (Coleoptera) from the Rovno amber: 1. adult morphology, Paleontol. J., 50, 293-296, https://doi.org/10.1134/S0031030116030047, 2016b.

Perkovsky, E. E.: Only half of Rovno amber Hymenopteran fauna is common with Baltic amber, Vestnik Zoologii, 52, 353-360, 2018.

Perkovsky, E. E. and Odnosum, V. K.: A new species of the scraptiid beetle genus Anaspis (Insecta: Coleoptera: Scraptiidae) from the Baltic and Rovno ambers (Upper Eocene of Eastern Europe), Paleontol. J., 43, 1092-1094, https://doi.org/10.1134/S0031030109090081, 2009.

Perkovsky, E. E., Zosimovich, V. Y., and Vlaskin, A. P.: Rovno amber insects: first results of analysis, Russian Entomol. J., 12, 119126, 2003.

Perkovsky, E. E., Rasnitsyn, A. P., Vlaskin, A. P., and Taraschuk, M. V.: A comparative analysis of the Baltic and Rovno amber arthropod faunas: representative samples, African Invertebrates, 48, 229-245, 2007.

Perkovsky, E. E., Zosimovich, V. Y., and Vlaskin, A. P.: Chapter 7: Rovno amber, in: Biodiversity of fossils in amber from the major world deposits, edited by: Penney, D., Siri Scientific Press, Manchester, 116-136, 2010a.

Perkovsky, E. E., Rasnitsyn, A. P., Vlaskin, A. P., and Rasnitsyn, S. P.: Community structure in the amber forest as revealed by the study of the arthropod syninclusia in the Rovno amber (Late Eocene of Ukraine), Acta Geol. Sin., 84, 954-958, 2010b.

Perkovsky, E. E., Rasnitsyn, A. P., Vlaskin, A. P., and Rasnitsyn, S. P.: Contribution to the study of the structure of amber forest 
communities based on analysis of syninclusions in the Rovno Amber (Late Eocene of Ukraine), Paleontol. J., 46, 293-301, https://doi.org/10.1134/S0031030112030136, 2012.

Petrov, A. V. and Perkovsky, E. E.: New species of bark beetles from the Rovno amber (Insecta: Coleoptera: Scolytidae), Paleontol. J., 42, 406-408, https://doi.org/10.1134/S0031030108040096, 2008.

Petrov, A. V. and Perkovsky, E. E.: A new genus and species of Scolytinae (Coleoptera: Curculionidae) from the Rovno amber, Paleontol. J., 52, 164-167, https://doi.org/10.1134/S0031030118020090, 2018.

Poinar Jr., G. O.: Life in amber, Stanford University Press, Stanford, 1-368, 1992.

Polilov, A. A. and Perkovsky, E. E.: New species of Late Eocene feather-winged beetles (Coleoptera, Ptiliidae) from Rovno and Baltic amber, Paleontol. J., 38, 664-668, 2004.

Rappsilber, I.: Fauna und Flora des Bitterfelder Bernsteinwaldes. Eine Auflistung der bis 2014 publizierten Organismentaxa aus dem Bitterfelder Bernstein, Halle (Salle), Ampyx-Verlag Dr. A. Stark, 1-78, 2016.

Rappsilber, I. and Wendel, A.: Bernsteingewinnung aus dem Bernsteinsee bei Bitterfeld und erste wissenschaftliche Ergebnisse, Mauritiana (Altenburg), 37, 87-112, 2019.

Reike, H.-P., Bukejs, A., Arlt, T., Kardjilov, N., and Manke, I.: Phase-contrast synchrotron microtomography reveals the internal morphology of a new fossil species of the Corticariasylvicola-group (Coleoptera: Latridiidae), Zootaxa, 4242, 578590, https://doi.org/10.11646/zootaxa.4242.3.9, 2017.

Reitter, E.: Die aussereuropäischen Dermestiden meiner Sammlung. Mit 70 Diagnosen neuer Arten, Verhandlungen des naturforschenden Vereines in Brünn, 19, 27-60, 1881.

Savkevich, S. S.: Yantar' [Amber], Leningrad, Nedra, 1-191, 1970 (in Russian).

Semenov, V. B., Perkovsky, E. E., and Petrenko, A. A.: First finding of the aleocharine beetle (Coleoptera, Staphylinidae, Aleocharinae) in Rovno amber, Dop. Akad. Nauk. Ukrain., 2001, 155-158, 2001.

Sergi, T. A. and Perkovsky, E. E.: Latridius usovae, a new species of the minute brown scavenger beetles (Coleoptera, Latridiidae) from Rovno amber, Vestnik Zoologii, 48, 319-324, 2014.
Sontag, E. and Szadziewski, R.: Biting midges (Diptera: Ceratopogonidae) in Eocene Baltic amber from the Rovno region (Ukraine), Polish Journal of Entomology, 80, 779-800, 2011.

Spahr, U.: Systematischer Katalog der Bernstein- und Kopal-Käfer (Coleoptera), Stuttgarter Beiträge zur Naturkunde (Ser. B), 80, 1-107, 1981.

Szwedo, J. and Sontag, E.: The traps of the "amber trap". How inclusions could trap scientists with enigmas, Denisia, 26, 155169, 2009.

Tshernyshev, S. E.: New taxa of soft-winged flower beetles (Coleoptera, Malachiidae) in Baltic and Rovno amber, Paleontol. J., 50, 953-962, https://doi.org/10.1134/S0031030116090021, 2016.

Weitschat, W.: Bitterfelder und baltischer Bernstein aus paläoklimatischer und paläontologischer Sicht, Exkursionsführer und Veröffentlichungen der Deutschen Gesellschaft für Geowissenschaften, 236, 88-97, 2008.

Weitschat, W. and Wichard, W.: Atlas of plants and animals in Baltic amber, Verlag Dr. Friedrich Pfeil, Munich, 1-256, 2002.

Weitschat, W. and Wichard, W.: Baltic amber, in: Biodiversity of fossils in amber from the major world deposits, edited by: Penney, D., Siri Scientific Press, Manchester, 80-115, 2010.

Wolfe, A. P., McKellar, R. C., Tappert, R., Sodhi, R. N. S., and Muehlenbachs, K.: Bitterfeld amber is not Baltic amber: Three geochemical tests and further constraints on the botanical affinities of succinite, Rev. Palaeobot. Palynol., 225, 21-32, https://doi.org/10.1016/j.revpalbo.2015.11.002, 2016.

Zhantiev, R. D.: New species of late Eocene dermestid beetles (Coleoptera, Dermestidae) from the Rovno and Baltic ambers, Paleontol. J., 40, 560-563, https://doi.org/10.1134/S0031030106050108, 2006.

Zherikhin, V. V. and Eskov, K. Yu.: Mesozoic and Lower Tertiary resins in former USSR, Estudios Museo Ciencias Naturales de Álava, 14, 119-131, 1999. 